HUMANIKA Vol. 23 No. 1 (2016) ISSN 1412-9418

Pergeseran Nilai-Nilai Budaya Pada Suku Bonai Sebagai Civic Culture Di Kecamatan Bonai Darussalam Kabupaten Rokan Hulu Provinsi Riau Ryan Prayogi, Endang Danial

\title{
PERGESERAN NILAI-NILAI BUDAYA PADA SUKU BONAI SEBAGAI CIVIC CULTURE DI KECAMATAN BONAI DARUSSALAM KABUPATEN ROKAN HULU PROVINSI RIAU
}

\author{
Oleh: \\ ${ }^{1}$ Ryan Prayogi, dan ${ }^{2}$ Endang Danial \\ ${ }^{1}$ Mahasiswa Pendidikan Kewarganegaraan SPs Universitas Pendidikan Indonesia \\ ${ }^{2}$ Dosen Departemen Pendidikan Kewarganegaraan SPs Universitas Pendidikan Indonesia \\ E-mail: Prayogi_ryan@yahoo.com
}

\begin{abstract}
This research was grounded by social problems, which is a shift of cultural values and global transformation with positive and negative values including waning identity tribe Bonai, such as change the culture in the form of traditional values in traditional ceremonies as a result of changes in the environment their lives, both the natural environment and the physical and social environment such as the loss of a sense of kinship, courtesy, honesty, and mutual cooperation. The findings in this study revealed that 1) the tribe Bonai a principle of life that becomes a guideline and regulations that must be adhered to by the tribal people Bonai hereditary implemented include: Birth, Circumcision Rosul, Employment, Education, Marriage Married, Leadership System Society, Death. 2) The shifting cultural mores which are currently experiencing a shift towards cultural values that include a shift in values Nativity, Circumcision Rosul, Marriage, and Ritual Dewo. 3) Preservation made to the successor or the younger generation by providing knowledge about the culture, following the race on culture or festival and explain the meanings contained in each ceremony they have done, executing each set of tribal Bonai traditions, which are birth, circumcision messenger, dewo mating and rituals for marriage. 4) Development of indigenous culture as do general should be imparted to young people from birth to adulthood through education and infomal also goes by way of natural or natural and spontaneous. In particular the development of the cultural values taught to elementary school through high school.
\end{abstract}

Keywords: A shift in Cultural Values, Cultural Bonai Ethnicity, Civic Culture

\section{PENDAHULUAN}

Indonesia merupakan suatu negara yang sangat kaya akan keanekaragaman budaya, hal ini dikarenakan Indonesia terdiri dari berbagai suku bangsa dimana masing-masing suku bangsa tersebut memiliki perbedaan dan keunikan baik dari segi bahasa daerah, adat istiadat, kebiasaan, dan berbagai hal lain yang memperkaya keanekaragaman dari budaya Indonesia itu sendiri. Sebagaimana pendapat Taylor (Horton \& Chester, 1996, hlm. 58) "Kebudayaan adalah kompleks keseluruhan dari pengetahuan, keyakinan, kesenian, moral, hukum, adat istiadat dan semua kemampuan dan kebiasaan yang lain yang diperoleh oleh seseorang sebagai anggota masyarakat" Selain itu Kebudayaan memiliki beberapa wujud yang meliputi: Pertama wujud kebudayaan sebagai ide, gagasan, nilai, atau norma; Kedua wujud kebudayaan sebagai aktifitas atau pola tindakan manusia dalam 
masyarakat; Ketiga adalah wujud kebudayaan sebagai benda-benda hasil karya manusia. Wujud kebudayaan ini bersifat konkret karena merupakan bendabenda dari segala hasil ciptaan, karya, tindakan, aktivitas, atau perbuatan manusia dalam masyarakat. Koentjaraningrat (2009, hlm. 150-153).

Menurut Koentjaraningrat (2009, hlm. 67) kebudayaan daerah sama dengan konsep suku bangsa. Suatu kebudayaan tidak terlepas dari pola kegiatan masyarakat. Keragaman budaya daerah bergantung pada faktor geografis. Semakin besar wilayahnya, maka makin komplek perbedaan kebudayaan satu dengan yang lain. Jika kita melihat dari ujung pulau Sumatera sampai ke pulau Irian tercatat sekitar 300 suku bangsa dengan bahasa, adat-istiadat, dan agama yang berbeda. Sementara itu, menurut Garna (2008, hlm. 141) budaya lokal merupakan bagian dari sebuah skema dari tingkatan budaya hierakis bukan berdasarkan baik dan buruk. Selain itu, Judistira K Garna juga mendefinisikan kebudayaan lokal adalah melengkapi kebudayaan regional, dan kebudayaan regional adalah bagian-bagian yang hakiki dalam bentukan kebudayaan nasional. Berbagai suku yang berada di Negara Kesatuan Republik Indonesia, ternyata secara realitas tidak sesuai dengan harapan dan cita-cita bangsa. Seperti persatuan dan kesatuan demi terwujudnya kemerdekaan Negara Indonesia seutuhnya, permasalahan saat ini berdasarkan faktanya, identitas budaya Indonesia sudah mulai memudar karena arus global, sehingga kondisi yang mengkhawatirkan ini perlu segera diselamatkan.

Departemen Sosial Indonesia memberikan istilah bagi suku marjinal ini menurut pola tempat tinggalnya: tidak menetap, setengah berpindah-pindah, dan sementara menetap. Departemen Sosial Republik Indonesia 1987, dikutip dari Hamidy, (1991, hlm. 5). Ada empat faktor yang menentukan peringkat isolasinya: (1) jarak geografis, (2) kurangnya fasilitas komunikasi dan teknologi modern, (3) kurangnya interaksi sosial dengan masyarakat yang lainnya, dan (4) penganut kepercayaan leluhur dan alam pikir primitif (Hamidy, 1991, hlm. 38-39). Menurut Smith (Nursid, Sumaatmadja, 2000, hlm. 68-69), menyatakan bahwa makna dari pergeseran tersebut merupakan peningkatan kemampuan sistem sosial, kemampuan sistem sosial memproses informasi-informasi, baik yang langsung maupun tidak langsung dan proses modernisasi ini sesuai dengan pilihan dan kebutuhan masyarakat. Menurut Suparlan, P. (2003, hlm. 29) nilai-nilai budaya adalah acuan bagi pemenuhan kebutuhan adab, yaitu kebutuhan-kebutuhan untuk mengetahui yang benar sebagai lawan dari yang salah, yang suci dari yang kotor, yang indah dari yang buruk, dan sebagainya. Nilai budaya yang miliki oleh suatu masyarakat bukanlah sesuatu yang statis, tetapi terus bergeser dan berubah dari satu generasi kegenerasi berikutnya. Pergeseran nilai budaya merupakan perubahan Nilai-nilai dalam suatu budaya yang nampak dari perilaku para anggota budaya yang dianut oleh kebudayaan tertentu. Pergeseran nilai budaya yang secara umum merupakan pengertian dari Perubahan sosial yang tidak dapat dilepaskan dari perubahan kebudayaan, saat budaya suatu masyarakat berubah, secara tidak langsung akan memberikan dampak bagi perubahan sosial masyarakat.

Pergeseran nilai-nilai budaya dalam masyarakat terjadi seiring pengaruh dari globalisasi dan pengaruh budaya lain. Perkembangan cyber space, internet, informasi elektronik dan digital, ditemui dalam kenyataan sering terlepas dari sistim nilai dan budaya. Perkembangan ini sangat cepat terkesan oleh generasi muda yang cenderung cepat dipengaruhi oleh elemenelemen baru yang merangsang. Hal ini disebabkan kebudayaan hasil dari adanya masyarakat, sehingga tidak akan adanya 
kebudayaan apabila tidak ada masyarakat yang mendukungnya dan tidak ada satupun masyarakat yang tidak memiliki kebudayaan. Pergeseran dan perubahan nilai-nilai ini sebagaimana terungkap dalam fenomena diatas menurut Kingsley yang dikutip oleh Selo Soemardjan (1990, hlm. 336) disebut sebagai perubahan sosial, yaitu "Perubahan-perubahan yang terjadi dalam struktur dan fungsi masyarakat".

Melalui nilai kearifan lokal merupakan upaya untuk mempertahakan sebuah budaya dalam suatu bangsa. Soebadio (Ayatrohaedi, 1986, hlm. 18-19) mengatakan local genius adalah 'cultural identity, identitas budaya bangsa yang menyebabkan bangsa tersebut mampu menyerap dan mengolah kebudayaan asing sesuai watak dan kemampuan sendiri'. Masyarakat Suku Bonai mengalami pergeseran nilai budaya. Salah satunya mengenai tradisi adat yang sudah tidak dilaksanakan ataupun dilestarikan hanya sebagian kecil saja di daerah Suku Bonai yang masih melestarikan kebudayaan, dari sebagian besar masyarakat Suku Bonai yang ada di kecamatan Bonai Darussalam sudah mulai bisa berbaur dengan masyarakat pendatang sehingga sebagian kecil yang masih mempertahankan tradisinya bahkan secara berpakaian dan bercocok tanam masih menggunakan cara adat mereka. Menurut Mack, D (dalam Pujiwiyana. 2010) bahwa gejala tradisi budaya yang bersifat fakta-fakta alami dan mitologis mulai ditinggalkan oleh sebagian masyarakat. Sebagian masyarakat mempunyai kecenderungan mengutamakan sarana dan pola pemikiran yang berasal dari budaya-budaya maju sambil menganaktirikan budaya sendiri dengan tradisi lama. Hal ini membuat sejumlah tokoh masyarakat Suku Bonai mulai berfikir kembali untuk mempertahankan kebudayaan Suku Bonai dan nilai kearifan lokal yang terdapat dalam kehidupannya agar lapisan masyarakat suku bonai turut serta melestarikan dan mempertahankan tradisi mereka yang sudah ada sejak dahulu. Oleh sebab itu, dalam upaya agar tidak terjadi pergeseran nilai - nilai kebudayaan pada Suku Bonai, salah satu bidang ilmu yang mengkaji tentang budaya daerah atau kearifan lokal yang terdapat di dalam warganegara adalah Civic Culture.

Permasalahan yang dihadapi dalam kebudayaan masyarakat Suku Bonai di daerah Bonai Darussalam antara lain, akibat dari pergeseran nilai - nilai budaya dan transfomasi global yang syarat dengan nilai positif dan negatif diantaranya memudarnya jati diri suku bonai seperti, perubahan kebudayaan yang berupa nilainilai tradisional dalam upacara adat sebagai akibat dari perubahan yang terjadi dalam lingkungan hidup mereka, baik lingkungan alam dan fisiknya maupun lingkungan sosialnya seperti hilangnya rasa kekeluargaan, sopan santun, kejujuran, dan gotong royong. Hal ini menyebabkan terjadinya pergeseran nilainilai budaya pada suku Bonai yang secara turun temurun dilaksanakan nenek moyangnya. Berdasarkan fenomena diatas, maka perlu perhatian dalam mendeskripsikan budaya suku Bonai, mengidentifikasi pergeseran nilai-nilai budaya pada masyarakat suku bonai. Hingga pada akhirnya, penelitian ini dianggap perlu untuk dikaji dalam aspek kebudayaan dan kearifan lokal suku Bonai dalam membentuk identitas bangsa dalam rangka membentuk bangsa yang berkarakter yang memiliki nilai-nilai civic culture. Oleh karena itu perlunya sebuah tulisan mengenai kebudayaan Suku Bonai. Hal demikian menarik untuk meneliti tentang Pergeseran Nilai-Nilai Budaya Pada Suku Bonai Sebagai Civic Culture di Kecamatan Bonai Darussalam Kabupaten Rokan Hulu Provinsi Riau? Pertanyaan 
demikian dapat dirinci lagi pada aspek permasalahan, yaitu:

1. Bagaimana deskripsi Nilai - nilai Budaya yang dianggap menjadi prinsip kehidupan masyarakat suku Bonai?

2. Bagaimana Pergeseran nilai-nilai yang terdapat dalam budaya masyarakat suku Bonai?

3. Bagaimana nilai-nilai budaya suku Bonai dilestarikan sebagai civic culture?

4. Bagaimana pengembangan nilai nilai budaya suku Bonai sebagai kearifan lokal?

\section{TINJAUAN PUSTAKA}

\subsection{Kebudayaan}

Menurut Koentjaraningrat (2009, hlm. 146) "culture merupakan kata asing yang artinya kebudayaan, berasal dari kata latin "colere" yang berarti mengolah atau mengerjakan, terutama mengolah sawah." Dalam arti ini berkembang arti culture sebagai segala upaya serta tindakan manusia untuk mengolah tanah dan mengubah alam dalam proses kehidupan manusia. Senada dengan pendapat diatas Taylor (Horton \& Chester, 1996, hlm. 5) kebudayaan adalah 'kompleks keseluruhan dari pengetahuan, keyakinan, kesenian, moral, hukum, adat istiadat dan semua kemampuan dan kebiasaan yang lain yang diperoleh oleh seseorang sebagai anggota masyarakat. Dalam hal ini, kebudayaan dalam masyarakat juga sering disebut dengan peradaban dalam bahasa inggris yang disebut dengan civilization. Dalam hal perdaban ini sering dikaji dalam masyarakat kota maju dan kompleks. Selain itu peradaban yang luas meliputi pengetahuan dalam masyarakat, kepercayaan dalam masyarkakat dan lainlain.

Sementara itu Menurut Wiranata (2011, hlm. 96-97) dari sekian banyak pemikiran para ahli tentang apakah sesungguhnya kebudayaan itu, secara umum inti pengertian kebudayaan:

1. Bahwa kebudayaan yang terdapat antara umat manusia itu sangat beraneka ragam,

2. Bahwa kebudayaan itu didapat dan diteruskan secara sosial melalui proses pembelajaran,

3. Bahwa kebudayaan itu terjabarkan dari komponen biologis, sosiologis, dan psikologis dari eksistensi manusia,

4. Bahwa kebudayaan itu berstruktur,

5. Bahwa kebudayaan itu memuat beberapa aspek,

6. Bahwa kebudayaan itu bersifat dinamis, dan

7. Bahwa nilai dalam kebudayaan itu bersifat relative

Melville J.Herkovits yang menyebutkan bahwa kebudayaan memiliki empat unsur pokok yaitu: a). Alat - alat teknologi, b). System ekonomi, c). Keluarga, d). Kekuasaan politik. Menurut Bronislaw Malinowski mengatakan empat unsur pokok yang meliputi: a. sistem norma sosial yang memungkinkan kerja sama antaranggota masyarakat untuk menyesuaikan diri dengan alam sekelilingnya, b. organisasi ekonomi, c. alat dan lembaga atau petugas untuk pendidikan, d. organisasi kekuatan (politik). Sementara itu, menurut Coteora (antropolog), berdasarkan wujudnya tersebut budaya memiliki beberapa unsur sebagai berikut: a). kebudayaan materil, b). kebudayaan nonmateril, c). lembaga sosial, d). sistem kepercayan, e). estetika, f). bahasa. Sulasman \& Gumilar (2013, hlm. 38). Menurut Koentjaraningrat (2003, hlm. 142) semua konsep yang kita perlukan untuk menganalisa proses-proses pergeseran masyarakat dan kebudayaan disebut sebagai dinamika sosial. Beberapa konsep tersebut antara lain sebagai berikut : 1). Proses belajar kebudayaan sendiri, yang terdiri dari internalisasi, sosialisasi, dan enkulturasi; 2). Evolusi kebudayaan 
dan difusi; 3). Proses pengenalan unsur unsur kebudayaan asing meliputi akulturasi dan asimilasi; 4). Proses pembauran atau inovasi atau penemuan baru.

\subsection{Pergeseran Nilai Budaya}

Pergeseran merupakan suatu perubahan secara sedikit demi sedikit atau berkala pada seorang yang dipengaruhi oleh perkara lain yang mengakibatkan perubahan pandangan hidup. Pendapat tersebut menegaskan bahwa, perubahan dari setiap diri seseorang tidak datang dengan begitu saja melaikan harus diusahakan dan diupayakan. Menurut Smith (Nursid, Sumaatmadja, 2000, hlm. 68-69), menyatakan bahwa makna dari pergeseran tersebut merupakan peningkatan kemampuan sistem sosial, kemampuan sistem sosial memproses informasi-informasi, baik yang langsung maupun tidak langsung dan proses modernisasi ini sesuai dengan pilihan dan kebutuhan masyarakat. Proses pergeseran nilai-nilai ini tidak terjadi secara spontan melainkan dilandasi oleh kesadaran dan waktu yang cukup lama menuju kearah suasana kehidupan yang lebih baik, secara tidak langsung pergeseran atau perubahan akan terjadi secara perlahan-lahan dan tanpa disadari.

Menurut Barth (dalam Sudrajat, dkk. 2015, hlm. 48) menjelaskan bahwa nilai adalah "the results of judgments made by an individual or the society as a whole which determine the relative importance or worth of a thing, idea, practice or believe". Penjelasan di atas dapat disimpulkan bahwa nilai merupakan hasil pertimbangan yang dibuat oleh seseorang atau masyarakat secara kelompok untuk menentukan penting atau berharganya suatu hal, gagasan, atau praktek. Sehingga dapat disimpulkan bahwa pergeseran nilai merupakan perubahan nilai - nilai yang dianut oleh suatu kelompok masyarakat yang ada karena suatu pengaruh nilai nilai dari luar masyarakat. Pergeseran nilai merupakan salah satu akibat yang dimunculkan dari adanya perubahan dalam kehidupan masyarakat itu sendiri. Menurut Suparlan, P. (2003, hlm. 29) nilai-nilai budaya adalah acuan bagi pemenuhan kebutuhan adab, yaitu kebutuhan-kebutuhan untuk mengetahui yang benar sebagai lawan dari yang salah, yang suci dari yang kotor, yang indah dari yang buruk, dan sebagainya.

Pergeseran nilai budaya merupakan perubahan Nilai-nilai dalam suatu budaya yang nampak dari perilaku para anggota budaya yang dianut oleh kebudayaan tertentu. Pergeseran nilai budaya yang secara umum merupakan pengertian dari Perubahan sosial yang tidak dapat dilepaskan dari perubahan kebudayaan, saat budaya suatu masyarakat berubah, secara tidak langsung akan memberikan dampak bagi perubahan sosial masyarakat. Pergeseran dan perubahan nilai-nilai ini sebagaimana terungkap dalam fenomena diatas menurut Kingsley yang dikutip oleh Selo Soemardjan (1990, hlm. 336) disebut sebagai perubahan sosial, yaitu "Perubahan-perubahan yang terjadi dalam struktur dan fungsi masyarakat". Sedangkan menurut Selo Soemardjan (1990, hlm. 337), perubahan sosial didefinisikan sebagai berikut:

"Segala perubahan-perubahan pada lembaga-lembaga kemasyarakatan di dalam suatu masyarakat, yang mempengaruhi sistem sosialnya, termasuk didalamnya nilai-nilai, sikap dan pola perilaku diantara kelompok-kelompok dalam masyarakat".

Perubahan sosial tidak terjadi dengan sendirinya melainkan disebabkan oleh banyak faktor, selain itu, perubahan sosial tidak berdiri sendiri melaikan memiliki kaitan dengan aspek kehidupan, baik pada individu maupun masyarakat, baik pada skala terbatas maupun luas, dan berlangsung cepat atau lambat. Sedangkan menurut Wibert Moore (dalam Jacobus Ranjabar, 2008, hlm 15) berpendapat 
bahwa perubahan sosial bukanlah suatu gejala masyarakat modern tetapi sebuah hal yang universal dalam pengalaman hidup manusia. Menurut Soerjono Soekanto (1990, hlm. 352), perubahan sosial di picu oleh bertambahnya atau berkurangnya pendudukan, adanya penemuan-penemuan baru, pertentangan (conflict), dan perubahan yang berasal dari lingkungan manusia.

\subsection{Civic Culture}

Istilah budaya kemasyarakatan atau civic culture diciptakan oleh Gabriel Almond \& Sidney Verba, (1963, hlm 8) dalam buku nya The Civic Culture untuk menjelaskan perilaku hubungan politik dan sosial yang dianggap penting bagi keberhasilan demokrasi modern. Dengan menggunakan teknik-teknik penelitian survei pada saat itu, Almond dan Verba melakukan pengkajian di lima negara, yakni: Inggris, Jerman, Italia, Meksiko, dan Amerika Serikat. Namun, dalam proses pengkajian mereka maka terjadi perubahan studi politik komparatif yang menjauh dari kecenderungan eksklusif dengan analisis mendasar terhadap studi perilaku komparatif.

Menurut Winataputra, (2012, hlm. 57) civic culture merupakan budaya yang menopang kewarganegaraan yang berisikan separangkat ide-ide yang dapat diwujudkan secara efektif dalam representasi kebudayaan untuk tujuan pembentukan identitas warganegara. Dalam hal ini, civic culture sangat diperlukan dalam pengembangan Pendidikan Kewarganegaraan. selain dari pada itu, Winataputra (2006, hlm. 58) menyatakan bahwa identitas warganegara yang bersumber dari civic culture perlu dikembangkan melalui Pendidikan Kewarganegaraan dalam berbagai bentuk dan latar belakang. Selain dari pada itu, Winataputra (2006, hlm. 62) Adapun unsur dari budaya kewarganegaran (civic culture) adalah "civic virtue atau kebajikan atau ahlak kewarganegaraan yang mencakup keterlibatan aktif warganegara, hubungan kesejajaran/egaliter, saling percaya dan toleran, kehidupan yang kooperatif, solidaritas, dan semangat kemasyarakatan." Konsep civic culture atau budaya Pancasila untuk Indonesia, terkait erat pada perkembangan democratic civil society atau masyarakat madani Pancasila yang mempersyaratkan warganya untuk melakukan proses individualisasi, dalam pengertian setiap orang harus belajar bagaimana melihat dirinya dan orang lain sebagai individu yang merdeka dan sama tidak lagi terikat oleh atribut-atribut khusus dalam konteks etnis, agama, atau kelas dalam masyarakat. Masyarakat sipil yang demokratis tidak mungkin berkembang tanpa perangkat budaya yang diperlukan untuk melahirkan warganya. Karena itu pula segera harus mempunyai komitmen untuk memperlakukan semua individu secara sama (Winataputra \& Budimansyah. 2012, hlm. 233).

\section{METODE}

Desain penelitian yang digunakan dalam pemecahan masalah ini dengan menggunakan pendekatan kualitatif. Pendekatan penelitian kualitatif disebut juga "pendekatan naturalistik karena situasi lapangan penelitian bersifat natural atau alamiah apa adanya, dan tidak manipulasi" (Cresswel,1998; Nasution,1996). Dalam penelitian ini, diharapkan peneliti dapat memperoleh informasi dan data yang akurat mengenai penelitian. Alasan lainnya mengapa peneliti memilih pendekatan kualitatif naturalistik adalah disebabkan data yang akan diperoleh dari penelitian ini di lapangan lebih banyak menyangkut perbuatan dang ungkapan kata-kata dari responden yang sedapat mungkin bersifat alami, tanpa adanya rekayasa serta pengaruh dari luar. 
Metode yang digunakan dalam penelitian menggunakan Metode Etnografi tentang konsepsi masyarakat suku Bonai sebagai pusat pembudayaan kompetensi termasuk jenis penelitian kualitatif. Penelitian etnografi mempelajari peristiwa kultural, menyajikan pandangan hidup subjek studi, merupakan model penelitian ilmu-ilmu sosial yang menggunakan landasan filsafat phenomenology (Kabuto, 2008; O'Reilly, 2005). Penelitian etnografi menurut Creswell (1994, hlm. 145) "fokus pada masyarakat, memilih "informan yang diketahui memiliki pandangan yang luas dan mendalam terhadap aktivitas masyarakat yang diteliti. Menekankan pada makna bagaimana masyarakat make sense kehidupannya, pengalaman, dan struktur dunianya sendiri."

Penulis merasa tertarik untuk meneliti mengenai pergeseran nilai-nilai budaya pada suku Bonai sebagai civic culture. Untuk memfokuskan proses penelitian, maka penulis memilih di Kecamatan Bonai Darussalam Kabupaten Rokan Hulu Provinsi Riau sebagai tempat yang dijadikan lokasi penelitian. Dalam kaitannya penetapan Partisipan Penelitian, maka ada beberapa kriteria yang digunakan yaitu "latar (setting), para pelaku (actors), peristiwa-peristiwa (events), dan proses (process)' (Miles dan Huberman, 2007, hlm. 57). Adapun Partisipan Penelitian adalah Pemangku Adat Suku Bonai, Tokoh Agama, Tokoh Pemuda, Camat Bonai Darussalam, Dinas Pendidikan, Dinas Pariwisata dan Kebudayaan, para ahli budaya yang ada di Kecamatan Bonai Darussalam. Dalam penelitian kualitiatif, pengumpulan data dilakukan di dalam "natural setting" (kondisi yang alamiah), sumber data primer, dan tehnik pengumpulan data yang banyak kepada observasi pada masyarakat suku Bonai serta mengamati tahapantahapan yang dilalui, observasi partisipatif, wawancara mendalam dengan tokoh-tokoh masyarakat Bonai, dokumentasi, dan gabungan triangulasi. Sedangkan untuk analisis data menggunakan reduksi data, display data, dan pengambilan kesimpulan/ verifikasi data. Serta untuk validitas data menggunakan triangulasi.

\section{HASIL}

\subsection{Deskripsi Nilai-Nilai Budaya Yang Di Anggap Menjadi Prinsip Kehidupan Masyarakat Suku Bonai}

Menurut peneliti bahwa dalam suku Bonai terdapat beberapa kebudayaan yang merupakan prinsip kehidupan yang menjadi suatu pedoman, pegangan, peraturan yang harus ditaati oleh masyarakat suku Bonai yang secara turun temurun warisan nenek moyang dilaksanakan meliputi: Kelahiran, Sunat Rosul, Pekerjaan, Pendidikan, Nikah Kawin, Sistem Kepemimpinan Masyarakat, Kematian. Pada prosesi Kelahiran dalam kehidupan masyarakat Suku Bonai yang sudah turun temurun dilaksanakan melalui tahapan kehamilan, upacara kelahiran, upacara turun mandi, upacara tindik asah.

Pada prosesi Sunat Rosul melalui tahapan pembuatan gelanggang, tepung tawar, sunatan, upah-upah. Sementara dalam pekerjaan masyarakat umunya mencari ikan (poikan), berladang, berkebun karet (gotah), berkebun kelapa sawit, setelah berkembangnya ekonomi sehingga mereka memiliki pekerjaan sebagai buruh pabrik, guru, pedagang, aparatur desa, pegawai kecamatan. Pada tingkat pendidikan masyarakat suku Bonai umunya sangat rendah dulunya karena daerah terisolir, maka sangat sulit untuk bersekolah karena umumnya pekerjaan mencari ikan dan berladang, dengan berkembangnya pembangunan dan infrastruktur sekarang ini anak-anak sudah bisa bersekolah ada yang SD, SMP, dan SMA bahkan ada yang melanjutkan ke perguruan tinggi. Pada tahapan Barolek 
godang dalam Nikah Kawin meliputi tahapan muanta kato, muanta tando, upacara nikah kawin yang didalamnya melalui tahapan pembuatan gelanggang, poncak silek, ijab kobul, malam buinai, koba, upah,upah dan upacara penutupan nikah kawin meliputi musik godang borogong, tarian (tari cegak dan tari buwong kuayang). Sedangkan dalam sistem kepemimpinan masyarakat suku Bonai pucuk suku di pimpin oleh Datuk Bendaro yang dipilih tidak melalui proses demokrasi melainkan diwariskan menurut aturan adat yang berlaku dalam masyarakat suku Bonai.

Sedangkan kematian merupakan akhir dari siklus kehidupan masyarakat suku Bonai meliputi Penyelenggaraan jenazah dan prosesi tambak kubuo. Kebudayaan yang dihasilkan dari siklus kehidupan menjadi sebuah karakter bagi masyarakat suku Bonai yang terdapat di Kecamatan Bonai Darussalam karena unsur-unsur tradisi dan kesenian menghiasi hampir seluruh tatanan kehidupan masyarakat Bonai dengan adanya kebudayaan yang adat istiadatnya dijunjung tinggi oleh masyarakat adat yang merupakan sebuah siklus kehidupan masyarakat yang senantiasa menjadi prinsip-prinsip kehidupan sejak dulu hingga kini dan dimasa yang akan datang.

\subsection{Pergeseran Nilai-Nilai Yang Terdapat Dalam Budaya Suku Bonai}

Menurut peneliti bahwa terdapat suatu kebudayaan yang adat istiadatnya dijunjung tinggi oleh masyarakat suku Bonai dimana adat istiadat tersebut merupakan sebuah siklus kehidupan masyarakat yang senantiasa menjadi suatu prinsip kehidupan yang dijalankan sebagai pedoman, pandangan dan peraturan yang sejak dulu diwariskan turun temurun dari nenek moyang masyarakat suku Bonai. Namun, adat istiadat tersebut saat ini mengalami pergeseran terhadap nilai-nilai budaya yang meliputi pergeseran nilai Kelahiran, Sunat Rosul, Nikah Kawin, dan Ritual Dewo. Dalam kehidupan masyarakat suku Bonai, tahapan kelahiran turun-temurun yang dilaksanakan mengalami pergeseran akibat perkembangan zaman yang terdapat pada upacara kelahiran yang tahapannya mengalami pergeseran dengan adanya puskesmas dilingkungan masyarakat sehingga mereka sudah tidak memakai dukun beranak sebagai membantu dalam prosesi kelahiran karena mereka mengganggap masih menggunakan cara tradisional dan memakai mantera-mantera serta perlengkapan yang susah dicari, sehingga bagi mereka melahirkan dipuskesmas dan melaksanakan syukuran serta cukur rambut sudah mewakili dari tradisi yang sebenarnya tidak sesuai dengan tradisi dalam upacara kelahiran.

Sementara itu dalam upacara sunat rosul sama halnya dengan upacara kelahiran yang sekarang ini masyarakat sudah banyak yang tidak melaksanakan upacara secara adat karena membutuhkan waktu dan tenaga serta biaya yang banyak sehingga masyarakat umumnya melaksanakan sunat rosul dengan membawa anaknya ke puskesmas ataupun balai pengobatan yang tidak membutuhkan biaya banyak sedangkan dalam pelaksanaannya sunatan mereka merasa yakin karena di tangangi oleh dokter ataupun manteri sunat yang berpengalaman ketimbang tukang sunat adat mereka.

Pergeseran nilai juga terjadi pada pelaksanaan tradisi perkawinan yang disebut Barolek Godang. Tahapan Barolek Godang yang meliputi muanta kato, muanta tando, pembuatan gelanggang, pencak silat, ijab kobul, upah - upah, koba dan penutupan nikah kawin. Pada acara penutupan nikah kawin biasanya di hibur dengan menampilkan koba merupakan tradisi lisan jenis cerita yang disampaikan dengan gaya nyanyian. Begitu juga dengan 
tarian-tarian seperti tarian cegak dan buwong kuayang yang sudah jarang ditampilkan dalam acara barolek godang yang merupakan kesenian khas dari masyarakat suku Bonai. Pada Ritual Dewo juga mengalami pergeseran yang ditandainya dengan berkembangnya pola fikir masyarakat dan adanya puskesmas dan poskesdes yang berada dilingkungan mereka selalu memberikan penyuluhan dan pengobatan gratis bagi masyarakat kurang mampu. Sehingga masyarakat bonai mulai berfikir untuk berobat ke puskesmas dari pada berobat pada pemantan yang selama ini dijadikan sebagai orang yang bisa menyembukan penyakit keluarganya.

\subsection{Nilai-Nilai Budaya Suku Bonai Dilestarikan Sebagai Civic Culture}

Menurut peneliti bahwa untuk mewarisi kebudayaan suku Bonai kepada penerus atau generasi muda dengan memberikan pengetahuan dan menjelaskan makna-makna yang terdapat pada setiap pelaksanaan upacara yang telah mereka lakukan dan melaksanakan setiap prosesi upacara adat suku Bonai yang meliputi, kelahiran, sunat rosul, nikah kawin dan ritual dewo. Oleh sebab itu, pelestariannya setiap prosesi adat harus dilaksanakan karena didalam konteks civic culture, kebudayaan suku Bonai terdapat nilai-nilai civic culture ditandai dengan adanya sikap warga negara yang meliputi, nilai solidaritas, nilai musyawarah, nilai kepercayaan, nilai gotong-royong, nilai tanggung jawab, nilai kebersamaan dan nilai religius. Supaya tidak mengalami pergeseran nilai-nilai budaya karena merupakan sebuah warisan dari nenek moyang kita sejak dahulu.

Maka, pelestariannya prosesi adat harus dilaksanakan dimulai dari prosesi kelahiran dengan cara melakukan setiap rangkaian upacara adat seperti upacara kelahiran, upacara turun mandi dan upacara tindik asah begitu juga dalam prosesi sunat rosul supaya tidak terjadi pergeseran didalam tahapan-tahapannya maupun pola fikir masyarakat suku Bonai. Sementara itu pada upacara nikah kawin (barolek godang) merupakan acara nikah kawin yang dilaksanakan selama tiga hari tiga malam yang harus dilestarikan dengan cara mewarisi kepada generasi muda dengan memberikan pengetahuan dan menjelaskan makna-maknanya serta mengikut sertakan pada setiap pelaksanaan upacara nikah kawin. Supaya tahapantahapan tidak berubah maupun bergeser yang diwariskan nenek moyang masyarakat bonai. Sehingga tradisi itu wajib dilestarikan karena nilai-nilai yang ada didalamnya meliputi solidaritas, musyawarah, kepercayaan, gotongroyong, tanggung jawab, kebersamaan dan religius tidak berubah sehingga para generasi muda yang ada dalam suku Bonai terhindar pergeseran nilai-nilai budayanya sendiri akibat dari perkembangan zaman. Pemerintah juga turut andil dalam melestarikan kebudayaan suku Bonai dengan mengundang stasiun televisi untuk mengeksplor budaya suku Bonai seperti acara jejak petualang Trans7 yang telah ditayangkan ke seluruh indonesia dan juga tarian Kuayang pada acara join performance art Indonesia-Singapore tahun 2011.

\subsection{Pengembangan Nilai-Nilai Budaya Suku Bonai Sebagai Kearifan Lokal}

Menurut peneliti bahwa untuk mengembangkan kebudayaan suku Bonai dilakukan dengan dua cara yang pertama secara umum dan yang kedua secara khusus. Secara umum harus ditanamkan kepada penerus atau generasi muda dari sejak lahir sampai dewasa melalui pendidikan infomal (keluarga) dan non formal (masyarakat) juga berjalan dengan cara alamiah atau natural dan spontan. Mengenalkan dan memberikan 
pengetahuan kebudayaan dan kearifan lokalnya suku Bonai supaya dapat diwariskan oleh masyarakat suku Bonai pada setiap pelaksanaan upacara adat yang mereka lakukan sesuai adat istiadat secara turun temurun. Secara khusus pengembangan nilai-nilai budaya suku bonai mulai diajarkan ke sekolah dasar sampai sekolah menengah atas supaya mereka lebih mencintai, mengetahui, dan melestarikan setiap rangkaian tradisi meliputi, kelahiran, sunat rosul, nikah kawin, ritual dewo dan kematian. Sehingga mereka tidak lupa akan tradisi turun temurun. Sedangkan dalam proses pembelajaran suku Bonai terdapatnya sebuah proses pendidikan dengan cara internalisasi, sosialisasi, dan enkulturasi. Dalam hal ini, masyarakat suku Bonai juga memiliki pengetahuan mengenai kebudaya-kebudayaan luar contohnya masyarakat yang ada dalam ruang lingkupnya seperti melayu, batak, jawa dan minang.

Sekarang ini generasi muda khususnya anak-anak sekolah sedang mendalami seni pertunjukan yang ada dalam kebudayaan suku Bonai yang diajarkan di sekolah seperti tarian cegak dan buwong kuayang dan Poncak silek secara natural. Serta memberikan pengetahuan kepada anak-anak mengenai selain adat dan kearifan lokal mereka masih ada suku-suku dalam ruang lingkup hidup kita seperti jawa, batak dan sukusuku yang lain berbaur didalam kehidupan sekitar mereka supaya masyarakat pendatang bisa mengenal dan menghargai tradisi suku Bonai. Pemerintah juga turut andil dalam melestarikan kebudayaan suku Bonai dengan membimbing anak-anak Bonai yang mahir dalam tarian-tarian untuk dapat mengikuti perlombaan serta mengundang stasiun televisi untuk mengeksplor budaya suku Bonai seperti acara jejak petualang Trans7 yang telah ditayangkan ke seluruh indonesia dan juga tarian Kuayang pada acara join performance art Indonesia-Singapore tahun 2011.

\section{PEMBAHASAN}

\subsection{Deskripsi Nilai-Nilai Budaya Yang Di Anggap Menjadi Prinsip Kehidupan Masyarakat Suku Bonai}

Menanamkan nilai merupakan proses penanaman dari diri sendiri. Akan tetapi, stimulus dari proses penanaman nilai dari diri sendiri dapat dilakukan melalui pintu institusional yakni melalui instusi kelembagaan yang ada misalnya keluarga, sekolah dan wadah-wadah kemasyarakatan yang dibentuk oleh sendiri oleh anggota masyarakat. Menurut Gordon Allport (1964) dalam Mulyana (2011, hlm. 9), bahwa nilai adalah keyakinan yang membuat seseorang bertindak atas dasar pilihannya. Sebagaimana dikemukakan oleh James M.Henslin, (2007, hlm. 48) bahwa:

"Mempelajari suatu kebudayaan berarti mempelajari nilai (value) orang, yaitu ide mengenai kehidupan yang dikehendaki. Mereka menggunakan istilah sanksi "sanction" untuk merujuk reaksi yang diperoleh orang karena menaati atau melanggar norma. Suatu sanksi positif menyatakan persetujuan terhadap diikutinya suatu norma. Sedangkan sanksi negatif mencerminkan ketidaksetujuan terhadap pelanggaran suatu norma".

Sistem nilai budaya merupakan tingkat yang paling tinggi dan paling abstrak dari adat istiadat. Hal itu disebabkan karena nilai budaya merupakan konsep mengenai sesuatu yang ada dalam alam pikiran sebagian masyarakat yang mereka anggap bernilai, berharga, dan penting dalam hidup sehingga dapat berfungsi sebagai suatu pedoman yang memberi arah dan orientasi pada kehidupan para masyarakat. Menurut Geertz (1973:hlm.89): Kebudayaan adalah 
"pola dari pengertian-pengertian atau makna yang terjalin secara menyeluruh dalam simbol-simbol yang ditransmisikan secara historis, suatu sistem mengenai konsepsi-konsepsi yang diwariskan dalam bentuk-bentuk simbolik yang dengan cara tersebut manusia berkomunikasi, melestarikan, dan mengembangkan pengetahuan dan sikap mereka terhadap kehidupan. Dalam proses ini, suku Bonai melakukan sebuah komunikasi dengan bahasa bonai melalui bahasa Bonai masyarakat dapat melestarikan kebudayaanya, selain itu, melalui siklus kehidupan dari melahirkan, upacara Nikah kawin, dan kematian, kebudayaan suku Bonai terus dilestarikan, dan dijadikan sebuah pengetahuan bagi masyarakat suku Bonai serta dijadikan sebuah sikap dalam bertindak demi terlaksananya upacaraupacara adat yang terdapat dalam masyarakat suku Bonai.

Selanjutnya Hamidy (2003, hlm. 7781) mengungkapkan dalam tradisi melayu Riau paling kurang ada empat macam konsep atau peringatan adat, salah satunya yaitu: Adat yang sebenarnya adat, yakni adat yang asli berupa adat, norma, hukum yang datang dari Allah yang berlaku segenap jagad raya ini. Menurut Junaidi Syam (2013, hlm. 119) bahwa pada dasarnya orang Bonai menyebut dirinya orang yang "indo ondak ko tongah" (tidak ingin maju), sama seperti orang talang mamak menyebut dirinya "orang langkah lama". Mereka merasa cukup hanya dengan makan ubi aro, mencari ikan, dan berburu dalam hutan untuk memenuhi kebutuhan lauk pauk".

Nilai-nilai dalam suatu budaya nampak dalam perilaku para anggota budaya yang dianut oleh budaya tersebut yang disebut dengan nilai normatif. Nilai normatif ini bisa diartikan nilai-nilai yang menjadi rujukan seseorang tentang apa yang baik atau buruk, benar atau salah, yang sejati atau palsu, positif atau negatif, dan sebagainya. Oleh karena itu, setiap kebudayaan yang ada dan berkembang dalam masyarakat selalu tidak terlepas dari nilai dan norma sebagai kaidah hidup serta petunjuk dalam bertindak dan bertingkah laku di masyarakat. Sejalan dengan pendapat diatas menurut Koentjaraningrat (1994, hlm. 25), bahwa:

"Nilai budaya merupakan konsepsikonsepsi yang hidup dalam alam pikiran sebagian besar anggota masyarakat, mengenai hal-hal yang harus mereka anggap amat bernilai dalam hidup. Nilai-nilai budaya menampakkan diri dalam kata-kata dan perilaku para anggota budaya yang dituntut oleh budaya tersebut. Nilai budaya yang dimiliki seseorang mempengaruhinya dalam menentukan alternatif, cara-cara, alat-alat, dan tujuan-tujuan perbuatan yang tersedia".

Maksud dari pendapat Koentjaraningrat diatas, bahwa nilai-nilai budaya yang berlaku dan berkembang di dalam masyarakat membentuk apa yang disebut pandangan hidup "worldview" masyarakat itu sendiri. Nilai budaya yang miliki oleh suatu masyarakat bukanlah sesuatu yang statis, tetapi terus bergeser dan berubah dari satu generasi kegenerasi berikutnya.

\subsection{Pergeseran Nilai-Nilai Yang Terdapat Dalam Budaya Suku Bonai}

Pergeseran merupakan suatu perubahan secara sedikit demi sedikit atau berkala pada seorang yang dipengaruhi oleh perkara lain yang mengakibatkan perubahan pandangan hidup. Pendapat tersebut menegaskan bahwa, perubahan dari setiap diri seseorang tidak datang dengan begitu saja melaikan harus diusahakan dan diupayakan. Proses pergeseran nilai-nilai ini tidak terjadi secara spontan melainkan dilandasi oleh kesadaran dan waktu yang cukup lama menuju kearah suasana kehidupan yang 
lebih baik, secara tidak langsung pergeseran atau perubahan akan terjadi secara perlahan-lahan dan tanpa disadari.

Menurut Smith (Nursid, Sumaatmadja, 2000, hlm. 68-69), menyatakan bahwa makna dari pergeseran tersebut merupakan peningkatan kemampuan sistem sosial, kemampuan sistem sosial memproses informasiinformasi, baik yang langsung maupun tidak langsung dan proses modernisasi ini sesuai dengan pilihan dan kebutuhan masyarakat. Proses pergeseran nilai-nilai ini tidak terjadi secara spontan melainkan dilandasi oleh kesadaran dan waktu yang cukup lama menuju kearah suasana kehidupan yang lebih baik, secara tidak langsung pergeseran atau perubahan akan terjadi secara perlahan-lahan dan tanpa disadari.

Sehingga dalam budaya suku Bonai mengalami sebuah pergeseran melalui nilai-nilai gotong-royong, musyawarah, solidaritas, kepercayaan, sikap kebersamaan sudah mulai pudar seiring perkembangan zaman, oleh karena itu, pergeseran disebabkan oleh beberapa faktor diantaranya faktor ekonomi, faktor religius, faktor pendidikan. Begitu juga dengan hasil penelitian Priska (2013) bahwa fenomena bergesernya nilai budaya dalam peran adat basandi sarak, sarak basandi kitabullah disebabkan karena masyarakat Minangkabau sudah meninggalkan sistem adat istiadat asli budaya Minangkabau. Masyarakat Minangkabau mudah terpengaruh kebudayaan lain dan meninggalkan apa yang telah menjadi kebiasaan mereka dari dulu. Kurangnya rasa memiliki dan kecintaan terhadap budaya sendiri membuat adat atau kebiasaan masyarakat Minangkabau perlahan-lahan diganti dengan yang baru.

Pergeseran nilai budaya yang secara umum merupakan pengertian dari Perubahan sosial yang tidak dapat dilepaskan dari perubahan kebudayaan, saat budaya suatu masyarakat berubah, secara tidak langsung akan memberikan dampak bagi perubahan sosial masyarakat. Menurut Kingsley yang dikutip oleh Selo Soemardjan (1990, hlm. 336) disebut sebagai perubahan sosial, yaitu "Perubahan-perubahan yang terjadi dalam struktur dan fungsi masyarakat". Sedangkan menurut Selo Soemardjan (1990, hlm. 337), perubahan sosial didefinisikan sebagai berikut: Segala perubahan-perubahan pada lembagalembaga kemasyarakatan di dalam suatu masyarakat, yang mempengaruhi sistem sosialnya, termasuk didalamnya nilai-nilai, sikap dan pola perilaku diantara kelompokkelompok dalam masyarakat. Sedangkan menurut Selo Soemardjan (1990, hlm. 337), perubahan sosial merupakan segala perubahan-perubahan pada lembagalembaga kemasyarakatan di dalam suatu masyarakat, yang mempengaruhi sistem sosialnya, termasuk didalamnya nilai-nilai, sikap dan pola perilaku diantara kelompokkelompok dalam masyarakat.

Berdasarkan penjelasan diatas, Pergeseran nilai suku bonai dapat didefinisikan sebagai perubahan nilai-nilai yang dianut oleh suatu kelompok masyarakat suku Bonai karena adanya pengaruh dari luar. Makna pergeseran yang penulis maksudkan adalah perubahan sesuatu yang telah ada dapat berupa perubahan nilai-nilai sosial, norma-norma sosial, pola prilaku, organisasi, susunan lembaga kemasyarakatan, kekuasaan kewenangan dan interaksi sosial. Pergeseran nilai budaya suku Bonai merupakan perubahan Nilai-nilai dalam suatu budaya yang nampak dari perilaku para anggota budaya yang dianut oleh kebudayaan tertentu. Pergeseran nilai budaya yang secara umum merupakan pengertian dari Perubahan sosial yang tidak dapat dilepaskan dari perubahan kebudayaan, saat budaya suatu masyarakat berubah, secara tidak langsung akan 
memberikan dampak bagi perubahan sosial masyarakat.

Senada dengan hasil penelitian Swis Tantoro, Nila Novia, (2014) bahwa perubahan pada tahapan perkawinan Suku Sakai terjadi karena adanya faktor pendorong, yaitu faktor internal dan faktor eksternal. Adapun faktor internalnya antara lain adalah agama, pola pikir yang telah maju, penduduk yang heterogen, dan keinginan dari masyarakat itu sendiri untuk berubah. Sedangkan faktor eksternalnya antara lain adalah pengaruh dari luar, kontak dengan masyarakat lain, dan pencampuran kebudayaan yang disebabkan oleh adanya perkawinan dan lain sebagainya. Sedangkan hasil temuan peneliti menunjukan bahwa faktor-faktor pergeseran nilai budaya suku Bonai pada upacara nikah kawin meliputi, faktor ekonomi, faktor religius dan faktor pendidikan senada dengan hasil peneliti yang diatas hanya saja dilihat dari berbagai faktor prosesi upacara adat masing-masing.

Sejalan dengan Pendapat Jacobus Ranjabar (2008, hlm.58-63) ciri-ciri perubahan sosial yaitu:

1. Diferential social organization.

2. Kemajuan di bidang ilmu pengetahuan dan teknologi mendorong perubahan pemikiran ideologi, politik, dan ekonomi.

3. Mobilitas

4. Culture conflict

5. Perubahan yang direncanakan dan perubahan yang tidak direncanakan.

6. Kontroversi (Pertentangan)

Secara umum, faktor yang menyebabkan terjadinya pergeseran nilainilai budaya, semua tidak dapat terlepas dari adanya perubahan sosial. Menurut Soerjono Soekanto (1990, hlm. 352), perubahan sosial di picu oleh bertambahnya atau berkurangnya pendudukan, adanya penemuan-penemuan baru, pertentangan (conflict), dan perubahan yang berasal dari lingkungan manusia.

Sebagaimana tentang perubahan sosial diatas dapat di tambahkan yaitu evolusi, difusi dan akulturasi yang dilandasi oleh inovasi. Sedangkan menurut Rogers (Enok,M, 2000, hlm. 134). Proses perubahan sosial mengalami tiga tahapan yaitu:

a) Invention, yaitu proses perubahan yang diciptakan dan dikembangkan di dalam masyarakat.

b) Diffusion, yaitu proses suatu ide-ide baru yang disampaikan melalui sistem hubungan sosial tertentu.

c) Consequence, yaitu proses yang terjadi dalam masyarakat sebagai adopsi maupun penolakan terhadap ide-ide baru.

Dalam ketiga tahapan ini menggambarkan bahwa perubahan kebudayaan suku Bonai menimbulkan sikap pro dan kontra di masyarakat. Perubahan kebudayaan menimbulkan unsur-unsur baru dan bertentangan dengan unsur yang lama sehingga mempengaruhi norma-norma dan nilai-nilai yang kemudian berpengaruh terhadap masyarakat itu sendiri.

Dalam hal ini, dapat disimpulkan bahwa pergeseran nilai-nilai yang terdapat dalam budaya suku Bonai akibat dari perubahan kebudayaan yang terdapat dilingkungan masyarakat sejalan dengan pendapat Soerjono Soekanto (1990, hlm. 352), perubahan sosial di picu oleh bertambahnya atau berkurangnya pendudukan, adanya penemuan-penemuan baru, pertentangan (conflict), dan perubahan yang berasal dari lingkungan manusia. Sehingga menimbulkan beberapa faktor yang mempengaruhi kebudayaan suku Bonai meliputi faktor ekonomi, faktor religius dan faktor pendidikan. Sehingga nilai-nilai didalamnya meliputi nilai gotong-royong, musyawarah, kepercayaan, solidaritas, sikap kebersamaan, 
kekompakan, persaudaraan, mengalami perubahan yang sangat berpengaruh terhadap kebudayaan suku Bonai yang selama ini sudah dilestarikan oleh nenek moyangnya.

\subsection{Nilai-Nilai Budaya Suku Bonai Dilestarikan Sebagai Civic Culture}

Masalah pelestarian dan perubahan bukanlah sesuatu hal yang bersifat mutlak sekali, dalam arti tidak ada suatu kebudayaan pun yang bersifat statis atau tidak mengalami perubahan, dikecualikan pada suatu budaya yang sudah diawetkan atau sudah mati. Kebudayaan apapun bentuknya pasti didalamnya ada unsur yang berubah dari keadaan aslinya, hai ini dipicu oleh munculnya perkembangan zaman yang menghampiri dengan perubahan atau unsur dinamisasi didalamnya, maka hal itu tidaklah dapat dipandang sebagai sebuah pelestarian budaya. Setiap kebudayaan pasti mengalami suatu perubahan sebagai akibat dari perkembangan zaman yang semakin pesat, maka diperlukan pemikiran mengenai kebudayaan itu sendiri, hal yang mana dari suatu unsur kebudayaan patut dijaga dan dilestarikan atau dipertahankan, dan mana unsur dari kebudayaan dapat mengalami perubahan. Menurut Widjaja 1986, (dalam Jacobus, 2006:115) mengartikan Pelestarian sebagai kegiatan atau yang dilakukan secara terus menerus, terarah dan terpadu guna mewujudkan tujuan tertentu yang mencerminkan adanya sesuatu yang tetap dan abadi, bersifat dinamis, luwes dan selektif. Pelestarian budaya adalah upaya untuk mempertahankan nilai-nilai seni budaya, nilai tradisional dengan mengembangkan perwujudan yang bersifat dinamis, luwes, dan selektif, serta menyesuaikan dengan situasi dan kondisi yang selalu berubah dan berkembang.

Dasar perkembangan kebudayaan, bisa dilihat dari berbagai macam faktor, menurut Koentjraningrat (2009, hlm. 184), perkembangan kebudayaan bisa dilihat dari proses (social dynamis) yaitu, prosesproses yang terpenting ada mengenai proses belajar kebudayaan. Diantara konsep-konsep yang terpenting ada mengenai proses belajar kebudayaan oleh warga masyarakat yang bersangkutan, yaitu internalisasi (internalization), sosialisasi (socialization), dan enkulturasi (enculturasion). Ada juga proses perkembangan kebudayaan umat manusia pada umumnya dan bentuk-bentuk kebudayaan sederhana, hingga bentukbentuk yang makin lama makin kompleks, yaitu evolusi kebudayaan (cultural evolution). Kemudian ada proses penyebaran kebudayaan secara geografi, terbawa oleh perpindahan bangsa-bangsa dimuka bumi, yaitu difusi (diffusion). Proses lain adalah proses belajar unsurunsur kebudayaan asing oleh warga masyarakat, yaitu proses akulturasi (acculturation) dan asimilasi (assimilation). Akhirnya ada proses pembaharuan atau inovasi (innovation), yang berkaitan dengan penemuan baru (discovery dan invention).

Berdasarkan hasil penelitian mengenai pelestarian sebagai civic culture maka dari itu mengacu kepada teori. Banyak cara dalam pelestarian nilai-nilai budaya sebagai civic culture dengan tujuan untuk mempertahankan kebudayaan dan eksistensi dari kebudayaan Nasional. Salah satunya dilakukan oleh William Lim dan Tan Hock Beng (Hamka, 2013:9). Strategi tersebut menghasilkan 4 konsep arsitektur kotemporer vernacular, yakni:

1. Reinvigorating tradition" "evoking the vernacular" by way of "a genuine reinvigoration of traditional craft wisdom"

2. Reinventing tradition" - "the search for new paradigms"

3. Extending tradition" - "using the vernacular in a modified manner" 
4. Reinterpreting tradition" - "the use of contemporary idioms" to transform traditional formaldevices in "refreshing ways"

Dengan melakukan upaya-upaya pelestarian melalui berbagai macam cara yang ada maka nilai-nilai budaya tersebut dapat diselamatkan keberadaannya dan tidak menghilang begitu saja. Menurut Winataputra (2012:57) civic culture merupakan "budaya yang menopang kewarganegaraan yang berisikan separangkat ide-ide yang dapat diwujudkan secara efektif dalam representasi kebudayaan untuk tujuan pembentukan identitas warganegara." Dalam konteks civic culture, kebudayaan suku Bonai terdapat nilai-nilai civic culture ditandai dengan adanya sikap warga negara berupa: solidaritas, musyawarah, kepercayaan, gotong-royong, tanggung jawab, kebersamaan dan religius. Sejalan dengan hasil penelitian terdahulu As'arie (2011) menyatakan bahwa: budaya tradisi pesta pecung kaitan dengan pengembangan civic culture yaitu: nilai kebersamaan, nilai kekeluargaan dan nilai gotong royong. Senada dengan temuan penelitian ini bahwa unsur dari budaya kewarganegaran (civic culture) adalah civic virtue atau kebajikan atau ahlak kewarganegaraan yang mencakup keterlibatan aktif warganegara, hubungan kesejajaran/egaliter, saling percaya dan toleran, kehidupan yang kooperatif, solidaritas, dan semangat kemasyarakatan (Winataputra, 2006 : 62). Menurut Muryati, S \& Srihadi (2013) bahwa upaya pelestarian budaya tradisional dilakukan dengan cara melibatkan generasi muda dalam hal kepanitian, maupun pelaksanaan, sehingga generasi muda tidak sekedar menjadi panitia tetapi juga menjadi pelaku. Pelaksanaan kegiatan tradisional memuat nilai-nilai: nilai ketuhanan, nilai sosial, nilai kerukunan, nilai budaya, nilai sejarah, nilai hiburan, nilai pendidikan, dan nilai ilmu pengetahuan. Kegiatan tradisional tetap dilaksanakan, dengan tujuan agar masyarakat Indonesia yang majemuk dari sisi budaya tidak kehilangan budaya daerahnya.

\subsection{Pengembangan Nilai-Nilai Budaya Suku Bonai Sebagai Kearifan Lokal}

Berdasarkan hasil penelitian mengenai pengembangan maka dari itu mengacu kepada teori Palupi (2007, hlm. 8) menyatakan pendidikan berbasis nilainilai budaya lokal dan nasional adalah "sebuah proses pendidikan yang mampu merefleksikan nilai-nilai biak lokal maupun nasional kepada peserta didik dengan tujuan untuk menumbuh kembangkan rasa kebanggaan terhadap tanah airnya yang akan menimbulkan rasa cinta pada tanah airnya". Senada dengan pendapat diatas, Winataputra (2012, hlm. 66) mengatakan pengembangan civic culture atau demokrasi dalam dari berbagai konteks, dalam hal ini untuk pendidikan formal (disekolah dan perguruan tinggi), non formal (pendidikan luar sekolah), dan Informal (pergaulan dirumah). Dalam proses pendidikan masyarakat suku Bonai memiliki pendidikan tetapi berjalan secara spontan dan natural. Di mana pendidikan dalam masyarakat suku Bonai melalui pendidikan in formal dan non formal.

Dalam masyarakat suku Bonai pendidikan dilakukan dengan memberikan pengetahuan kepada anak-anak dari mereka sejak lahir hingga meranjak dewasa. Dalam hal ini, dalam konsepsi pengetahuan dikenal dengan Internalisasi. Senada dengan pendapat Koentjaraningrat (2003, hlm. 142) internalisasi adalah "proses yang berlangsung sepanjang hidup individu, yaitu mulai saat ia dilahirkan sampai akhir hayatnya. Sepanjang hayatnya seorang individu terus belajar untuk mengolah segala perasaan, hasrat, 
nafsu, dan emosi yang kemudian membentuk kepribadiannya." Selajutnya Menurut Fathoni (2006, hlm. 24) proses internalisasi tergantung dari bakat yang dipunyai dalam gen manusia untuk mengembangkan berbagai macam perasaan, hasrat, nafsu, dan emosinya. Tetapi semua itu juga tergantung dengan pengaruh dari berbagai macam lingkungan sosial dan budayanya.

Dalam pengembangan nilai-nilai budaya sebagai kearifan lokal dalam masyarakat suku Bonai melakukan sebuah proses pendidikan yang lakukan masyarakat adat dengan cara pembudayaan dalam keluarga dan masyarakat. Dalam prosesnya suku Bonai menyesuaikan pikiran serta sikap terhadap adat, sistem norma, serta dan aturan-aturan dalam masyarakat, yang mana menjelaskan kepada anak-anak kami tentang adat dan aturan-aturan adat yang tidak boleh dilanggar. Selanjutnya menurut Sutarto (2006, hlm. 1) "kearifan atau kecendekiaan lokal (adat) yang digunakan sebagai pedoman dalam kehidupan bermasyarakat merupakan bagian sentral tradisi". Lebih lanjut Sutarto menjelaskan bahwa tradisi adalah kebiasaan, turun temurun yang mencerminkan keberadaban para pendukungnya. Lebih lanjut Alwasih, et al (2009, hlm. 51) menyatakan ada beberapa ciri kearifan lokal yaitu :

1. Berdasarkan pengamalan;

2. Teruji setelah digunakan berabadabad;

3. Dapat diadaptasi dengan kultur kini;

4. Padu dalam praktik keseharian masyarakat dan lembaga;

5. Lazim dilakukan oleh individu atau masyarakat secara keseluruhan;

6. Bersifat dinamis dan terus berubah;

7. Sangat terkait dengan sistem kepercayaan;

Dari paparan diatas dapat dipahami bahwa kearifan lokal adalah seluruh gagasan, nilai, pengetahuan, aktivitas dan benda-benda budaya spesifik dan dibanggakan yang menjadi identitas dan jati diri suatu komunitas atau kelompok etnis tertentu. Sementara itu Keraf (dalam Budimansyah. 2002) menegaskan bahwa "kearifan lokal adalah semua bentuk pengetahuan, keyakinan, pemahaman atau wawasan serta adat kebiasaan atau etika yang menuntun perilaku manusia dalam kehidupan didalam komunitas ekologis. Semua bentuk kearifan lokal ini dihayati, dipraktekkan, diajarkan dan diwariskan dari generasi ke generasi sekaligus membentuk pola perilaku manusia terhadap sesama manusia, alam maupun gaib". Secara umum karakteristik lokal memberikan pandangan tentang kearifan lokal telah digunakan secara turun menurun oleh para pelaku budayanya, kearifan lokal tidak akan pernah lepas dari ruang lingkup kebudayaanya, kepercayaan dan keterkaitan antara lingkungan alam dan sosial yang ada di sekitarnya. Berdasarkan hasil penelitian dan pembahasan di atas, dapat dikatakan bahwa pengembangan nilai-nilai budaya sebagai kearifan lokal dilakukan masyarakat suku Bonai berjalan dengan cara natural atau alamiah dan spontan. Serta mengajarkan pendidikan tentang kebudayaan dan nilai-nilai kearifan lokal pada pendidikan formal, non formal, dan in formal dalam masyarakat suku Bonai.

Oleh karena itu, menurut peneliti sebaiknya dalam menjaga kearifan lokal budaya suku Bonai harus dilaksanakan program-program yang mendukung pengembangan kearifan lokal budaya hal ini sejalan dengan hasil penelitian Siswandi (2011, hlm. 66) bahwa dalam upaya menjaga kearifan lokal pada masa mendatang, maka program-programnya adalah: a) Penguatan semangat masyarakat adat dan agama, b) Peningkatan pemahaman, kesadaran, kepedulian, dan partisipasi masyarakat menuju kondisi masyarakat yang arif lingkungan, c) Penyediaan payung hukum, d) Mendorong 
terciptanya Desa Purwogondo sebagai Desa Wisata Religi. Sedangkan menurut Zulkarnain, (2008, hlm. 70) Upaya untuk mengembalikan kepercayaan masyarakat terhadap kekuatan kearifan lokal untuk pelestarian sumberdaya pesisir perlu dilakukan, yaitu dengan memperhatikan beberapa hal berikut: (i) pengembangan kelembagaan masyarakat lokal dan (ii) peningkatan apresiasi budaya lokal, seperti pantangan dan larangan, petatah-petitih dan peribahasa adat. Serta masyarakat tersebut perlu untuk terus menjaga nilainilai yang terkandung dalam semboyan ini dalam kehidupan sehari-hari.

\section{SIMPULAN}

Berdasarkan sejumlah temuan penelitian yang diuraikan pada bahasan sebelumnya maka secara umum dapat disimpulkan bahwa pergeseran nilai-nilai budaya suku Bonai sebagai civic culture, bahwa dalam kebudayaan suku Bonai terdapat sebuah nilai-nilai budaya yang dianggap menjadi prinsip kehidupan masyarakat suku Bonai yang mana adat istiadat itu dijunjung tinggi oleh masyarakat adat sebagai sebuah siklus kehidupan yang senantiasa menjadi prinsip-prinsip kehidupan yang menjadi suatu pedoman, pegangan, peraturan yang harus ditaati oleh masyarakat suku Bonai yang secara turun temurun warisan nenek moyang dilaksanakan meliputi: Kelahiran, Sunat Rosul, Pekerjaan, Pendidikan, Nikah Kawin, Sistem Kepemimpinan Masyarakat, Kematian.

Sedangkan yang mengalami pergeseran kebudayaan dimana adat istiadat tersebut merupakan sebuah siklus kehidupan masyarakat yang senantiasa menjadi suatu prinsip kehidupan yang dijalankan sebagai pedoman, pandangan dan peraturan yang sejak dulu diwariskan turun temurun dari nenek moyang masyarakat suku Bonai. Namun, adat istiadat tersebut saat ini mengalami pergeseran terhadap nilai-nilai budaya yang meliputi pergeseran nilai Kelahiran, Sunat Rosul, Nikah Kawin, dan Ritual Dewo (upacara pengobatan), dalam tradisi kelahiran meliputi proses upacara melahirkan, sunat rosul yang mengalami pergeseran dalam tatacara sunatan yang sudah bergeser dari tahapan-tahapan sunat rosul, sedangkan dalam nikah kawin (Barolek Godang) yang mengalami pergeseran dalam prosesi adatnya yaitu dalam prosesi barolek godang meliputi, upah-upah, tarian Cegak. dan didalam Ritual dewo. Dalam pelestarian yang dilakukan oleh masyarakat suku Bonai kepada penerus atau generasi muda dengan memberikan pengetahuan mengenai kebudayaan kepada generasi muda, mengikuti perlombaan mengenai kebudayaan maupun festival dan menjelaskan makna-makna yang terdapat pada setiap pelaksanaan upacara yang telah mereka lakukan, melaksanakan setiap rangkaian tradisi suku Bonai meliputi, kelahiran, sunat rosul, nikah kawin dan ritual dewo.

Pengembangan budaya sebagai kearifan lokal dalam masyarakat suku Bonai dilakukan dengan dua cara yang pertama secara umum dan yang kedua secara khusus. Secara umum harus ditanamkan kepada penerus atau generasi muda dari sejak lahir sampai dewasa melalui pendidikan infomal (keluarga) dan non formal (masyarakat) juga berjalan dengan cara alamiah atau natural dan spontan. Secara khusus pengembangan nilai-nilai budaya suku bonai mulai diajarkan ke sekolah dasar sampai sekolah menengah atas supaya mereka lebih mencintai, mengetahui, dan melestarikan setiap rangkaian tradisi meliputi, kelahiran, sunat rosul, nikah kawin, ritual dewo dan kematian. Sehingga mereka tidak lupa akan tradisi turun temurun. 


\section{DAFTAR PUSTAKA}

Alwasih, C., Suryadi,K., Karyono,T. (2009). Etnopedagogi: Landasan Praktek Pendidikan dan Pendidikan Guru. Bandung; Kiblat Universitas Pendidikan Indonesia.

Ayatrohaedi. (1986). Keperibadian

budaya bangsa (Local Genius). Jakarta:

Pustaka Jaya.

Budimansyah, D. (2006). Pendidikan nilai moral dalam dimensi pendidikan kewarganegaraan. Bandung: Lab. PKn-FPIPS UPI.

Creswell, John.W. (2010). Research design: Pendekatan kualitatif, kuantitatif, dan mixed. Yogyakarta: Pustaka Pelajar.

Enok, M. (2000). Kebudayaan masyarakat modern. Malang: Universitas Muhammadiyah Malang.

Fathoni, A. (2006). Antropologi sosial budaya. Jakarta: PT Rineka Cipta.

Garna, J. K. (2008). Budaya Sunda: Melintasi waktu menantang masa depan. Bandung: Lemlit Unpad--.

Geertz, C. (1973). The interpretation of cultures: Selected Essays.New York: Basic Books.

Hamka, ST. (2013). Kearifan Lokal dalam arsitektur. Universitas Briwijaya Malang: Program Pasca Sarjana Arsitektur Lingkungan Binaan.Tidak di Terbitkan.

Hamidy (2003) Jagad melayu dalam lintas budaya . Pekanbaru: Bilik Kreatif Press.
Horton, P. B \& Chester L. H. (1996). Sosiologi. Jakarta: Penerbit Erlangga.

Koentjaraningrat. (2003). Pengantar antropologi I. Jakarta: PT Rineka Cipta. (2009). Pengantar ilmu antropologi. Jakarta: Rineka Cipta.

Miles \& Huberman. (2007). Analisis data kualitatif buku sumber tentang metode-motode baru. Jakarta: Universitas Indoneisa Press.

Mulyana, R. (2011). Mengartikulasikan pendidikan nilai. Bandung: Alfabeta.

Ranjabar, J. (2008). Perubahan sosial "Teori-teori dan proses perubahan sosial serta teori pembangunan. Bandung: Alfabeta.

Soekanto, S. (1990). Sosiologi suatu pengantar. Jakarta: Raja Grafindo Persada.

Soemardjan, S. (1990). Perubahan sosial di Yogyakarta. Yogyakarta: Gajah Mada University Press.

Sulasman \& Gumilar, S. (2013). Teoriteori kebudayaan dari teori hingga aplikasi. Bandung. CV Pustaka Setia.

Sumaatmadja, N. (2000). Manusia dalam konteks sosial budaya dan lingkungan hidup. Bandung. Alfabeta. 
HUMANIKA Vol. 23 No. 1 (2016) ISSN 1412-9418

Pergeseran Nilai-Nilai Budaya Pada Suku Bonai Sebagai Civic Culture Di Kecamatan Bonai Darussalam Kabupaten Rokan Hulu Provinsi Riau Ryan Prayogi, Endang Danial

Syam, J. (2013). Cerita rakyat rokan Hulu. Pasir Pengarayan : Dinas Kebudayaan dan Pariwisata Kabupaten Rokan Hulu.

Winataputra,U.S. (2006). Pendidikan kewarganegaraan dalam prespektif pendidikan untuk mencerdaskan kehidupan bangsa,(Gagasan, instrumentasi, dan praksisi). Bandung : Widya Aksara Press.

(2012). Pendidikan kewarganegaraan dalam perspektif pendidikan untuk mencerdaskan kehidupan bangsa (gagasan, instrumentasi, dan praksis). Bandung: Widya Aksara Press.

Winataputra, U.S dan Budimansyah, B. (2012). Civic education: Konteks, Landasan, bahan ajar, dan kultur kelas. Program Studi Pendidikan Kewarganegaraan SPS UPI Bandung.

As'arie. D. (2012). Suatu Kajian Tentang Nilai Budaya Pesta Pecung di Masyarakat Kesugengan Kidul Kabupaten Cirebon ditinjau dari "Civic Culture. (Skripsi). FIPS, Universitas Pendidikan Indonesia.

Gabriel dan Sidney Verba. (1989). Civic Culture: Political Ettitudes and Democracy in Five Nations. SAGE Publications. (Hlm,20-23).

Muryati, S. \& Srihadi. (2013). Pelestarian budaya nasional melalui kegiatan tradisional. Jurnal. 20 (3), hlm. 100-113.
Palupi, L.S. (2007). Menigkatkan rasa cinta tanah aiar dengan pendidikan berbasisi nilai-nilai budaya. Prespektif Psikologi : tidak diterbitkan.

Priska. (2013). Fenomena sosial masyarakat minangkabau dalam lirik lagu ciptaan agus taher. Jurnal Mahasiswa, hlm. 1-13. FBS Universitas Negeri Padang. Padang.

Pujiwiyana. (2010). Perubahan perilaku masyarakat ditinjau dari sudut budaya. Jurnal Seni dan Budaya. 1 (1), hlm. 5-14.

Sudrajat, dkk. (2015). Muatan nilai-nilai karakter melalui permainan tradisional di Paud Among Siwi, Panggungharjo, Sewon, Bantul. Jurnal JIPSINDO. 2 (1), hlm. 4465.

Suparlan, P. (2003). Bhinneka tunggal ika: keanekaragaman sukubangsa atau kebudayaan. Jurnal Antropologi Indonesia. 72(1), hlm. 29.

Swis, T. \& Novia, N. (2014). Perubahan adat perkawinan suku sakai di pemukiman buluh kasap kopelapip kecamatan Mandau. Jurnal online mahasiswa Bidang ilmu sosial dan ilmu politik,1 (1), hlm. 1-12.

Zulkarnain. (2008). Kearifan lokal dalam pemanfaatan dan pelestarian sumberdaya pesisir (Studi kasus di desa Panglima Raja kecamatan Concong kabupaten Indragiri Hilir propinsi Riau). Jurnal Agribisnis Kerakyatan. 1 (1), hlm. 69-84. 